\title{
LIBRARY RULES
}

1. Applications for books may be made in person, or by letter addressed to the American Mathematical Societr, 501 West 116th Street, New York. Members may, if they desire, apply in person directly to the superintendent of the loaning department of the Columbia University Library, where the Society's library is deposited. Books will be delivered directly to those applying in person, and will be sent to other applicants by express at the expense of the borrowers.

2. A book may be kept four weeks from the date of leaving the library, but the loan may be renewed from time to time by writing to the Society in advance of the day when the book is due.

3. Borrowers should return the books in person or by prepaid express. 
